\title{
KAZAKHSTAN'S CHALLENGE: THE THREAT POSED BY ASTANA'S ETHNIC RUSSIAN MINORITY AND WHAT IT MEANS FOR INTERNATIONAL LAW
}

\section{Davis L. Florick ${ }^{1}$}

\begin{abstract}
For two centuries Kazakhstan functioned under the yoke of Russian and Soviet imperialism. Perhaps the most lasting legacy of the period is the large ethnic Russian minority in northern Kazakhstan. Over the last twenty-five years since Astana declared its independence there have been little if any noticeable signs of ethnic tensions in the state. However, the Kremlin's use of ethnic Russian minorities in both Georgia and the Ukraine as justification for aggressive military action in both states' internal affairs has proven disconcerting for many of Russia's neighbors. Perhaps compounding matters further has been the lack of a response in kind by the international community. In the absence of more demonstrative action there is growing concern in Eurasia that the Putin Administration has established a new precedent in regional policy matters. Regardless, Kazakhstan must develop a coherent diplomatic and strategic planning campaign to build the necessary means and mechanisms to deter potential Russian aggression. Promoting cooperative engagement opportunities with its regional neighbors and international partners offers the necessary forcefulness to potentially dissuade future Russian aggression. Holistic engagement to strengthen defense, economic, and social levers will demonstrate to all involved that Astana has the tools at its disposal to curb foreign aggression.
\end{abstract}

Keywords: international politics - Kazakhstan - territorial conflicts - sovereignty - international law

\section{INTRODUCTION}

The global community's acceptable justifications for military conflict have been further constrained by growing aversions to unacceptable losses of life and property, yet Russia appears more willing to confront its Eurasian neighbors despite only a hint of legitimacy. In recent years, Moscow has argued that invasions of both Georgia and the Ukraine were necessary due to threats to ethnic Russians and the state's national interests. Yet originally "the Kremlin has [had] been stirring separatist movements in the east of Ukraine, in particular in the Donetsk and Kharkiv regions" ("Crimea Votes” para 8). Such assertive actions suggest Moscow has engineered crises in the region to justify its involvement abroad. Regarding both Georgia and the Ukraine, organizations such as the European Union (EU), North Atlantic Treaty Organization (NATO), and the United Nations (UN) entities intended to prevent conflict - have failed to deter Russian aggression. Consequently, important

${ }^{1}$ Asian World Center, Creighton University, United States. E-mail: davisflorick@creighton.edu vol.08, nº. 03, Rio de Janeiro, 2015.pp. 1555-1582 
stakeholders in other vulnerable states have begun calling the current international legal and political architecture into question. The global community - deeply rooted in legal instruments that took decades if not centuries to formulate and motivated in large part by the devastation of two world wars - could now be significantly impugned by Moscow’s increasing assertiveness.

Arguably, the most pressing challenge today lies not in resolving the territorial issues in Georgia and the Ukraine but in preventing the next conflict. Unfortunately for the global community, many of the unstated factors that motivated Russian intervention against Tbilisi and Kiev have not dissipated. A struggling economy, domestic political unrest, and a worsening demographic situation are just some of the variables contributing to the Putin Administration's decision calculus. With that in mind, where might the next war on Russia's periphery emerge? To the west, Belarus, the Baltic States, Norway, and Finland either maintain cordial relations with Russia or are supported by NATO. Along the border with the Russian Far East lie China, Japan, Mongolia, and North Korea. While it is not inconceivable that conflict might emerge with Beijing or Tokyo, such an aggressive maneuver by Moscow is highly unlikely given the accompanying drawbacks. As a result, it is likely Central Asia that will be the next victim of the Kremlin's drive for territorial acquisition. In particular, Kazakhstan with a substantial ethnic Russian minority faces significant risks. "Incendiary claims by Russian nationalists to parts of 'southern Siberia' (ie, northern Kazakhstan) — disavowed by Moscow but only languidly" ("Bear" para 3) — do little to assuage the Nazarbayev Administration's concerns. To dissuade Moscow from further asserting itself through force along its periphery requires a concerted effort on the part of Astana.

More than just identifying the potential for conflict, prudence necessitates a thorough review of the factors that could motivate or deter Russian military aggression. Gaining a better understanding of the Kremlin's decision making processes is invaluable, because

Nearly a quarter-century after the collapse of the Soviet Union, the West faces a greater threat from the East than at any point during the cold war. Even during the Cuban missile crisis of 1962, Soviet leaders were constrained by the Politburo and memories of the Second World War. Now, according to Russia's chief propagandist, Dmitry Kiselev, even a decision about the use of nuclear arms 'will be taken personally by Mr Putin, who has the undoubted support of the Russian people.' ("What Russia Wants” para 4)

Analyzing historic, legal, and political variables that are likely to either encourage or dissuade Moscow's assertiveness can contribute significantly to understanding the dynamics at play. By so doing, outside observers can better come to terms with the role international law plays in the Kremlin's decision making. This analysis will assist Kazakhstan in crafting a deterrence strategy that can serve as a symbol to rally the support of its allies and partners. To be effective, such a plan must combine defense, economic, and social elements that, taken collectively, will offer more substantial international legal underpinnings for Astana’s position. From a strategic 
standpoint, moving forward, assessing the likely factors that will impact Moscow's decision calculus in a future incursion in Central Asia is vital in order to deter such aggression.

\section{FACTORS MOTIVATING A RUSSIAN INCURSION INTO KAZAKHSTAN}

At the outset, one must recognize that Moscow is burdened with a number of challenges that many states across the international community are now faced with. As previously alluded to, the Kremlin has a variety of defense, economic, and social challenges that, if not alleviated, could seriously hinder its policy options over the long term. The Putin Administration specifically views the decreasing ethnic Russian population, diminishing real growth in gross domestic product (GDP), and shifting outlook in the energy economy as threats to the very survival of the regime. What makes Russia unique is that in some quarters it still views itself locked in a struggle with Europe and the United States (US) - ostensibly NATO. "A revised military doctrine signed by Mr. Putin in December identified 'reinforcement of NATO's offensive capacities directly on Russia's borders, and measures taken to deploy a global anti-missile defence system' in central Europe as the greatest threats Russia faces" ("What Russia Wants" para 20). Furthermore, at times the Kremlin has raised the risks of confrontation with its AsiaPacific neighbors. This behavior represents an additional complicating factor in Russia's decision calculus which could motivate the Putin Administration to assert itself in the strategically vital region of Central Asia. Consequently, while states in Western Europe, North America, and East Asia may view their evolving domestic, regional, and strategic landscapes as simply new obstacles they must adjust to and, by doing so, overcome, the Putin Administration regards these emerging problems as threats to regime survival. In response to the many challenges Russia faces, viewing historical, legal, and political factors from Moscow's perspective to then better comprehend why and how the Kremlin might look to intercede in Kazakhstan seems prudent.

\section{HISTORICAL PERSPECTIVE}

Looking back at regional dynamics over the last few centuries is important if one wishes to understand Russia's perspective on its role in Central Asia. Kazakhstan first emerged conceptually as a state in the fifteenth and sixteenth centuries. The community was largely formed of Cuman, Kipchak, Mongol and Turkic tribes; however, a wide variety of nomadic groups would gradually be incorporated. Unfortunately for the Kazaks, they were not the only cultural body struggling to assert its dominion in Central Asia. The Persians, Dzungars, Kalmyks, and others all pressed their claims along the Kazak borders. For a period, this near-constant state of warfare produced a strong Kazak state that was able to extend its western and northern reach. The Kazaks area of influence even extended to Russia's eastern most settlements. Tragically, according to the Russian narrative, these migrant settlers were victim to Kazak raiding parties bent on death and enslavement. Moscow's choice in 
characterization is important, because in establishing Russians as sedentary and Kazaks as nomadic an image of transient steppe horsemen contributes to the erosion of statehood. The Kremlin has used the image of stateless barbarians as an allusion to draw similarities to Huns, Mongols, and others in the minds of Europeans. Furthermore, "in August [2014], Mr. Putin humiliated Kazakhstan by saying the country had no history and then mustered troops for exercises near the border" ("The New Silk Road" para 5). It was the carefully articulated rhetoric from Moscow that allowed these troop movements to go unnoticed in Europe and the US. While there is some truth to these assertions, they are also the marks of considerable overreach. By the eighteenth century, the Kazak state had fragmented, but into three pieces; while that break up did allow for an even greater dispersion of authority in Central Asia, it did not lead to a liquidation of Kazak culture. It would therefore be only natural that Russia's imperial designs would spread to the region, offering stability as they came; yet leading to the partial assimilation of Kazak culture.

The Tsarist Empire ushered in a new era in Central Asia. Rather than disparate ethnic groups warring amongst each other, Russia came to dominate the region up to its borders with Iran, Afghanistan, Great Britain's India, and China. Where there had previously been centuries of conflict and hardship, peace was assured through war between Moscow and London. With greater order and stability and given Russia's burgeoning population, the national government of Russia recognized its new territories represented a potential opportunity. The Tsar's officials encouraged hundreds of thousands of ethnic Russians to emigrate to Kazakhstan and elsewhere in Central Asia. "In the minds of many [Russian] administrators, only under governmental regulation could Russian peasants, romanticized as hard-working and thrifty, secure the productivity and success of the steppe colony, while demonstrating the benefits of sedentarism [sic] to the mobile pastoralist Kazakhs" (Campbell 424). Soon the demographic balance in the region would begin to shift, and Russia would exert its cultural, economic, and governmental influence over Central Asia. The Soviet era to follow would further represent a fundamental alteration in the relationship between the broader Russian state and its Kazak republic.

Bolshevik rule led to far greater defense, economic, and social integration with the Central Asian republics. From a defense standpoint, the Soviet Union placed tremendous emphasis on this region because of its isolation. Moscow could concentrate strategic forces and industries in the area to minimize due to distance the threat the US could pose. In a similar fashion, the communists valued the natural resources and geographic isolation of Kazakhstan from an economic standpoint. For instance, the Soviets placed tremendous value in developing their strategic rocket industry and commensurate launch facilities in the region. "From Baikonurnow in central Kazakhstan, then in the Soviet Union — Sputnik and Laika the dog blasted off in the 1950s, and Yuri Gagarin shot into orbit and fame in 1961" ("Kazakhstan's Spaceport" para 1). To operate many of these enterprises, the Soviets encouraged ethnic Russian migration into Central Asia. At the same time, however, 
encouraging demographic changes was not done for purely positive reasons. Like elsewhere, the Soviets engaged in social engineering as a means to reduce the homogeneity of various ethnic groups within their own traditional borders. In this case, encouraging Russian migration would lead to the Kazaks becoming a minority in their own state with the result being civil and political conformity. Perhaps even more tragic, though, was the use of Central Asia and the Russian Far East as tools to divide remove and integrate Russian political dissidents and potential separatist movements from the Soviet heartland and integrate them with other ethnic minorities. The uprooting and further integration of cultural groups in the Soviet Union would have a lasting impact on the lives of millions of people. As a result of the investments and gerrymandering that occurred during the Soviet era, Russia today has substantial interests in Kazakhstan's future.

In the post-Soviet period, Russia first rejected its traditional role along its periphery. However, at the turn of the new century, the Putin Administration changed the national dialogue. Senior leaders in the Kremlin came to view Boris Yeltsin's desire to shift its focus toward an emphasis on its internal structure as a fatal flaw. Vladimir Putin and his inner circle began reemphasizing regional policy in Eurasia as a means to return Russia to its former glory. In the case of Kazakhstan, this has meant a greater emphasis on what Moscow views as its historic role. Case in point, the Eurasian Union was recently proposed as a largely Russian-dominated entity, but with Belarussian and Kazak membership. This organization would set fiscal and monetary policies for the states involved. Particularly disconcerting is the role population totals will play in shaping policy outcomes. With an overwhelming majority thanks to its population figures, Moscow has positioned itself to be able to set the course for the other member states. It is important to note that "along Kazakhstan's 7,000 km border with Russia lie towns with large ethnic-Russian populations. In many, such as Oskemen in the industrial north-east, Russians outnumber Kazakhs" ("Kazakhstan" para 4). An observer can begin to see how it would be only natural for Moscow to desire a greater role in Kazakhstan. From a historical vantage point, this organizational construct simply returns the region to its nineteenth and twentieth century traditions.

\section{INTERNATIONAL LAW CONTEXT}

Legally Russia can play a limited role along its periphery, but Moscow has gone to great lengths to justify its actions in Georgia and the Ukraine through two lines of effort. First, particularly in the case of Tbilisi, the Kremlin attempted to claim that the national government was targeting the Russian minority populations in Abkhazia and South Ossetia. Moscow argued that when ethnic Russians are persecuted Russia has an obligation to intercede. This is not unlike claims other states have made at various times to justify their actions abroad. Second, particularly in the activities in Crimea, Russia argued for self-determination of the local domestic population. In the same manner as NATO became involved in the Serbian conflict in Kosovo in 1999, Moscow 
argued that the pursuit of freedom amongst a minority justified military involvement. Indeed, "Russia tried to justify its annexation of Crimea by citing various historical precedents, ranging from Kosovo to the Falkland Islands. It had argued that Crimea, which was transferred to Ukraine in 1954 by Nikita Khrushchev, historically belonged to Russia" ("Crimea Votes" para 7). The underlying theme in both cases is that Russia proposed its action as permissible due to precedence established by the Americans and Europeans.

Moscow has attempted to establish the legitimacy of its military involvement abroad as simply a necessary measure to protect ethnic Russian minorities - even making the claim they are Russian citizens. When speaking of Moscow's incursion against Tbilisi, for example, "Sweden's foreign minister tartly noted recalled Hitler's justifications of Nazi invasions. Anyway, most of the 'Russian citizens' in Georgia's South Ossetia and Abkhazia had been handed their passports fairly recently, presumably in preparation for this foray" ("The War in Georgia” para 3). While few current conflicts help advocate the legal underpinnings of this course of action, a number of historic scenarios exist that help justify such actions. A famous case where the need for a state to protect a similar ethnicity abroad took place in China during the nineteenth century. Aggressive actions taken on the part of the Chinese against European missionaries and business entrepreneurs were regarded as a threat to Europeans that necessitated further military incursions from the Great Powers. Saddam Hussein made a similar case in the run-up to the Iran-Iraq War. While he would later fall out of favor, the international community looked at Iraq's invasion of Iran as a reasonable effort undertaken as a means to serve Sunni minorities in southern Iran. In both cases, the broader global audience overlooked the aggressiveness of military action due to the notion that ethnic minorities were being oppressed. Today Moscow is attempting to use similar claims to justify its involvement in protecting Russian minorities abroad.

The Chinese example is worth studying because of how the positions Europeans took at the time are similar to what the Russians have done today. On multiple occasions, Chinese killed or injured foreign citizens living within its boundaries. For instance, "in 1870 an anti-missionary riot at Tianjin left nineteen Europeans dead. Five years later a British official was killed near the Burmese frontier. For this China was forced to accept the Zhefu Convention of 1876, an unequal treaty" (Roberts 299). While a number of plausible explanations exist for these mishaps, the end result was that the Europeans and Japanese routinely capitalized upon the deaths of their citizens by sending troops into broader stretches of Chinese territory. The Qing Dynasty would then be forced into a humiliating settlement that relinquished further sovereignty. However, because the Europeans became involved in China as a result of a perceived need to protect their citizens, Russia has utilized this precedent for its actions abroad in order to help justify Moscow's decisions to become involved in places such as Georgia and, theoretically, Kazakhstan. 
In a similar vein, Iraq explained its actions in Iran through the threat the Shi'a dominated government in Tehran posed to its Sunni minority. Baghdad argued that the new regime under Ayatollah Khomeini posed a grave risk to the Sunni Arab minority in southern Iran. "Khuzestan - whose liberation had been another of Saddam's war aims" (Fisk 200) — was portrayed as a disenfranchised and maltreated region. Given the considerable political upheaval that had taken place once the Shah fell and the concern over the new theocratic regime, it was plausible that others in the region and internationally would excuse Iraqi aggression. A similar justification has been put forward by Russia. Most troubling, Moscow has attempted to argue that countries like Georgia and the Ukraine have been abusing the rights of ethnic Russians in their territories. Thus the Russians have used the same tactics as Iraq did thirty years ago. Sadly, Moscow has to some degree been able to convince others of Kiev and Tbilisi's aggressive actions. If nothing else, the international community has had a difficult time in countering the Kremlin's claims.

The Kremlin has also attempted to argue that its actions are in support of self-determination movements. Particularly in the case of Crimea, but even in Abkhazia, the Donbas, and South Ossetia, Russia has argued that quasi-Russian nationalistic movements have emerged. Intriguingly, in the case of Crimea, the Putin Administration suggested that independence had been achieved. Only after the peninsula had asserted its sovereignty did the population then request admission into the Russian Federation. However, in the other instances, there has been no formal annexation to date, thereby allowing the Kremlin to continue promulgating the message of independence. Thus, "Russia invaded Georgia under the pretext of protecting the separatist zone of South Ossetia from attack by Georgian troops" (Schoen and Kaylan 96). Since then the Kremlin has argued that independent states have emerged in Abkhazia, the Donbas, and South Ossetia. Moscow's desire to justify its actions by then creating small states should come as no surprise to many. In point of fact, self-determination has played a looming role in many conflicts in recent memory. Specifically, the recent war in Kosovo in 1999 has long been held by Russia as the justification for such action on its part. Moscow's ability to reconcile its foreign policies with those of the Europeans and the US elsewhere has proven extremely valuable in explaining away adventures in its near abroad.

\section{POLITICAL VANTAGE POINT}

From a foreign policy standpoint, a number of factors are driving Russia's assertiveness in its near abroad. While a plethora of contributing elements most likely exist, three overarching themes must be appreciated because they trump many current deterrent mechanisms used in the region. First, for some time the Kremlin has grown increasingly wary of its declining influence along its periphery. NATO expansion; the role the US has played intermittently in Central Asia since the terror attacks of September 1 $1^{\text {th }}, 2001$; and China's burgeoning influence 
across Asia have all come at the cost of the one-time Soviet realm. Worryingly, since the Kremlin's activities in the Ukraine began in early 2014, its rhetoric and relations with the West have become even more antagonistic. "The threat of sanctions by America and the EU only made the Kremlin more belligerent. In a recent television wrap-up, the Kremlin's chief propagandist, Dmitry Kiselev, said Russia was the only country 'capable of reducing America into a nuclear dust" ("Crimea Votes" para 4). Second, repatriating ethnic Russian enclaves serves as a means to offset the declining Slavic population at home. In light of the rising Muslim minority populations, this is of particular import for Moscow. Third, along with ethnic Russians, the physical and human capital acquisitions the Kremlin has made carry the potential to slightly curb the deterioration of the future economic outlook. For a state with serious GDP growth concerns, this is not small victory. The three aforementioned variables certainly do not represent an all-encompassing list, but they do begin to provide a framework for Moscow's political decision calculus.

To understand the Putin Administration thought process in openly engaging in military conflict along its periphery, one must recognize its concerns over the changing security landscape. During the Cold War, the US effectively contained the more dominant continental power. As the communist regime began to fall and the new Russian Federation emerged, the Yeltsin Administration could not maintain its influence in its near abroad. "In the early 1990s, it pulled back from Central Asia as its own economy and armed services when into decline" (Rashid 67). While the new government encouraged the formation of the Commonwealth of Independent States (CIS) as an economic partnership amongst the former Soviet republics and the Collective Security Treaty Organization (CSTO) as a mutual-defense agreement amongst many of the same states, these organizations proved unable to prevent NATO expansion in Europe. Soon virtually all of the former Warsaw Pact member states joined the Euro-Atlantic alliance, causing great consternation and concern in Moscow. Furthermore, in recent years the former Soviet republics have begun improving relations with the US. The Putin Administration fervently supports this idea as they have argued that

The Maidan uprising and ousting of Viktor Yanukovych as Ukraine's president were engineered by American special services to move NATO closer to Russia's borders. Once Mr Yanukovych had gone, American envoys offered Ukraine's interim government $\$ 25$ billion to place missile defences on the Russian border, in order to shift the balance of nuclear power towards America. Russia had no choice but to act. ("What Russia Wants" para 5)

The decision of many of its former allies and partners to abandon Russia only further strengthened those within Moscow that believed Washington was attempting to tighten the noose.

In response to the increased US presence along its periphery, Russia has gone to considerable lengths to counter its perceived containment. Within the given context, it only makes sense for the Kremlin to establish a new series of satellite states on its borders. Already Russia has established partnerships in the Caucasus and 
Eastern Europe to avoid any further encroachments on the part of the Europeans. However, there remains a vulnerability in Central Asia with authoritative regimes capable of shifting alliances away from Russia at a moment's notice. "Kazakhstan will always have the option of turning toward China if the likes of Putin become too heavy-handed" (Kaplan 185-6). If the Putin Administration can encourage ethnic Russians in Kazakhstan's north to separate, then a gap will form creating a reliable client state. From a political standpoint, establishing satellite states is a prudent step to avoid further US and European encroachment.

Creating semi-autonomous countries along Russia's periphery is a necessary step to minimize the substantial demographic shortfalls Moscow now faces. Of note, "according to U.S. Census Bureau statistics, in the years between 2000 and 2008, Russia's average annual fertility rate was 1.34" (Berman 15) with no sign of this problem abating. In particular, with the Slavic population decreasing and the various Muslim ethnic minorities increasing in numbers, there may come a time when ethnic Russians are no longer the majority in their own state. This shift is all the more troubling for the Putin Administration because of historical tendencies. Ethnic Russians have been conquering various Muslim groups since the fourteenth century. Even today there are an unusually high number of hate crimes where the victims are non-Slavs that must be addressed. Consequently, promoting sovereignty amongst ethnic Russians beyond the Kremlin's borders serves as a means to increase the number of Slavs under the government's control. This maneuver holds the potential to offset some of the population losses Moscow is facing, at least in the short term.

In a similar fashion, the Putin Administration has failed to invest in good governance necessary to foster the human and physical capital needed sustain long term economic growth. "Official institutions, the kind the West depends on for governing, have functioned so inefficiently in Russia because their real role is largely to hide the workings of a collection of crony arrangements informed by a traditional political culture that has shaped the country's history for centuries" (Feifer 7). Unfortunately, with Russian finances headed in the wrong direction, there may not be enough time to alter the current dynamics through investment alone. Rather, by establishing semi-autonomous partner states, Moscow is able to leverage both human and physical capabilities. The Kremlin can tap into these new states to bring people, goods, and services to Russia. In essence the new territorial acquisitions, particularly if Russia could acquire additional ethnic Slavs from Kazakhstan, could mitigate some of the current challenges Moscow is facing.

The Russian Federation under its current leadership appears unwilling to make the difficult decisions necessary to resolve the challenges it faces. Resolving problems associated with economics like a lack of human and physical capital investment would, in all probability, weaken state controls. The Putin Administration cannot afford empowering the Russian people in this manner because doing so could lead to the same problems the Soviet Union experienced under Mikhail Gorbachev's leadership. However, by establishing satellite states from a 
distance, Moscow can benefit from their production potential without taking on the same obstacles. In a similar vein, investing in the social programs necessary to improve family planning could unveil some of the weaknesses of the current regime. In particular, Russians may ask themselves why their government has not prioritized solutions to social ills in the past. Ultimately, Vladimir Putin cannot afford exposing the shortfalls his government has allowed to emerge on the domestic side. Simply repatriating ethnic Russians affords the state a short term resolution to its problems. Attempting to alleviate these obstacles through acquiring satellite states does not resolve the endemic policy vulnerabilities the Kremlin is promulgating. Likewise, "now that the economy is shrinking, the threat of war is needed to legitimise his rule" ("What Russia Wants" para 16). From the perspective of the Putin Administration, further conflict and development of semi-autonomous states along its periphery offers quick solutions.

\section{KAZAKHSTAN'S LIKELY VIEWPOINT ON CONFLICT}

Astana has long functioned under the ire of Moscow. Russia has posed a near-constant threat to Kazakhstan over the last two centuries. Unfortunately, recent policy decisions from the Kremlin have only served to elevate fears on the part of the former Soviet republics. Attempts to bring ethnic Russian enclaves all across its periphery back into Moscow's orbit through the formation of semi-autonomous states risk delegitimizing the sovereignty of the former Soviet republics. To prevent repeats of what has already befallen Georgia and the Ukraine, other states along Russia's periphery must take resolute action to deter future Moscow-backed aggression. While some may urge these states to pursue international law mechanisms to dissuade the Kremlin, Astana must also rely on historical and political tools. For instance, Kazakhstan "is developing three super-giant 'elephant' oil, gas, and condensate fields, two on the Caspian Sea, with major investment from Western multinationals" (Kaplan 185), thereby fortifying the stakes from outside interests. Only by analyzing background material and current trends in all three categories can Kazakhstan hope to prevent Russian aggression on its northern border.

\section{HISTORICAL PERSPECTIVE}

Kazakhstan has a long and storied history of independence, and only in recent centuries has it been subjugated to Russian dominion. It will be important for the government in Astana to articulate that it has long been a sovereign nation. Highlighting its enduring legacy and the role Moscow played as it "began to solidify control in Central Asia in the early nineteenth century, when Russian trade in the area increased" (Kaplan 183) and how the Soviet Union went dramatically further by relegating the Kazak people to an ethnic minority are critical. Specifically, the international community must understand that the rights of the Russian minority have 
been respected since independence. In coming to terms not only with the gerrymandering the Soviets embarked upon in Kazakhstan but also with how the current regime has taken steps to protect its minorities will be important from the perspective of international norms of behavior. Astana has to be able to message the broader global audience that it has done nothing to warrant Russian aggression. Articulating Kazakhstan's historical place in Central Asia begins to erode the Kremlin's arguments.

From the fourteenth and fifteenth century onward, the Kazak people functioned with their own national identity. Assembled from a collection of Mongol, Turkic, and other nomadic tribes, a new community formed on the steppe. On that open landscape the Kazak people would come to overlap "western Siberia and Central Asia and stretch 1,800 miles from the Caspian Sea in the west to Outer Mongolia in the east. The Urals peter out in Kazakhstan's northwest; the foothills of the Tien Shan begin in Kazakhstan's southeast" (Kaplan 185). In other words, it is a truly vast space. Importantly though, this cultural block was just one of a number of burgeoning nations in Central Asia. Despite challenges from virtually every direction, the Kazaks were able to emerge as a single nation-state amongst the disparate groups in the region. Indeed, the emergence of Kazakhstan as a construct developed at roughly the same point as Russia's development into a nation-state. Consequently, neither possesses an advantage in terms of longevity. Unfortunately for Astana, while the Kazaks emerged as their own people, geography worked against the fledgling state.

During the sixteenth and seventeenth centuries, the community struggled to maintain its continuity on open land. Other peoples from across Central Asia challenged the very survival of the Kazaks. It was only a matter of time before the tension from outside led to internecine clan violence. When the nation divided into three groups - the Great, Middle, and Little hordes - the nation's overall fate was sealed. Interestingly, this period led to future nationalistic delineations amongst "Kazak clan-tribal history concentrating on a clarification of lineage and genetic roots within the three Kazak Hordes (italicized in original text)" (Sarsembayev 322). And while Kazakhstan survived under various leaders during the 1700s, as a fractured entity it could not hope to hold out indefinitely. As Russian settlers continued their march east, it was only a matter of time before the Kazaks would be subsumed.

Tragically, Tsarist Russia saw Kazakhstan as nothing more than a thoroughfare to reach both South Asia and the Pacific Ocean. The Russian Empire saw Central Asians as backwards people that needed Russian guidance. It introduced an administrative system as well as military garrisons and barracks to assert its dominion in the region. Russia then went one step further by forcing the Kazaks into teaching Russian language in the schools and across all governmental organizations. The Tsar's policies were so well-received that when the decision was made to annex Kazakhstan in the 1860s, he was met with fierce resistance. Once dissension was brushed aside, the nomadic lifestyle and livestock-based economy gradually eroded. Soon Russia began 
encouraging emigration to Kazakhstan. Exponentially increasing numbers of peasants moved to the northern province of Semirechye, particularly once the Trans-Aral Railway was formed. Indeed, the Imperial emigration policies would significantly contribute to a scenario where "the Kazaks became a minority in their own land for the first time in history - the Kazaks were 30 per cent and the Russians 42.7 per cent of Kazakhstan's population in 1959" (Sarsembayev 326). By the time of the collapse of the Tsars, the process of socially engineering the region was well under way.

The Soviet Union would take the Tsarist policies and significantly increase the cultural integration processes in the region. "It is said that the Kazak population decreased from 6 million in 1915 to 4,120,000 in 1930. Then, some 1,750,000 had died from starvation, epidemics and execution over 40 per cent of the entire population; 200,000 fled into neighbouring countries and remained there, and 453,000 took refuge and stayed in neighbouring Soviet republics" (Sarsembayev 325). Through absolute authoritarian control, the Communists were able to forcibly move people from across the country at will. The central government rose to power through a revolt, and so it was acutely threatened by the slightest hint of rebellion. In particular, during the earliest years of the Bolshevik rise to power many of the Soviet republics had attempted to break away. Recalling the conflicts that ensued as these states were subsumed back into the Soviet sphere, the Communists endeavored never to allow such self-determination aspirations to emerge again. As a result of early history, the Soviets went to great pains to relocate ethnic groups they viewed as potentially nationalistic. This meant that groups such as the Tatars and Chechens were evicted from their homes in the Ukraine and Caucuses and sent to Central Asia and Siberia. Moscow then went one step further by encouraging Russian emigration to what had been inherently non-Russian ethnic regions. This decision was made to further dilute the cohesiveness and potential restiveness of various key population centers. For instance, northern Kazakhstan, northern Georgia, and Crimea in the Ukraine all were plagued by Moscow's emphasis on Russian migration. "The Soviets created individual states out of the vast Central Asian steppe and tableland that did not cohere with ethnic borders, so that if any tried to secede it would have been impossible" (Kaplan 183). Through a systematic process of gerrymandering and social engineering, the Soviets were able to significantly erode the fighting potential of the ethnic minorities under their jurisdiction.

When the communist government fell and Kazakhstan declared independence, it is important to note the manner with which self-determination was handled. The Kazak people did not turn against their Russian neighbors. Given the Kremlin's arguments in other instances that Russians have been negatively treated, it cannot be stated more resolutely that this problem did not arise in Kazakhstan. In recent years, the Kazak people have slowly begun to recover from life under the Soviet yoke. Particularly as an east-west trading center, Astana has become a major economic thoroughfare. Arguably the most controversial element to post-Soviet Kazak behavior has been "renaming streets and cities, a common occurrence since independence in 1991, allowing the authorities 
to distance themselves from their Soviet and, before that, Russian colonial pasts, and to foster a new national identity" (Kazakhstan's Name” para 4). Its role as a burgeoning trading power carries the potential to elevate the state's status in the coming years as it further attempts to fortify its autonomy.

\section{INTERNATIONAL LAW PERSPECTIVE}

Kazakhstan has a unique position if one were to examine possible Russian aggression through a legal perspective. Certainly both states' membership in CSTO and the Shanghai Cooperation Organization (SCO) would play an interesting role in any conflict scenario. Both treaties either formally or informally espouse collective security. It remains unclear how Moscow could manipulate the facts to justify military action on the territory of a fellow treaty member. Particularly when considering that China would have to accept the Kremlin's reasoning as it pertains to SCO, an observer would most likely find it highly unlikely that a Russian incursion would be taken lightly since "China is not just challenging the existing world order. Slowly, messily and, apparently with no clear end in view, it is building a new one" ("Pax Sinica" para 10) that would take a step back if the Kremlin asserts its dominion in Central Asia once more. Furthermore, Kazakhstan could easily turn to the UN to define an appropriate justification for conflict. While Russia may be able to argue that one exists, the lack of proof especially given the Kazak government's record on minority tolerance - would present an obstacle. Clearly Astana has a strong legal footing for arguing the legality of a potential Russian incursion. The real question must be focused on the effort mechanisms in place to seek recrimination.

Established in 2002, CSTO is a collective security organization comprising many of the former Soviet republics. Current members include Armenia, Belarus, Kazakhstan, Kyrgyzstan, Russia, and Tajikistan. "Regional coordination, cast in the grandiose language of regional integration, creates a basis for political solidarity between state leaders and their protection against or resistance to a perceived interventionist agenda" (Allison 188). The organization charter clearly affirms that the participating states will refrain from the threat of force against one another. A scenario in which Russia were to launch an incursion into Kazakhstan would appear to violate this specific requirement. In all likelihood, the other CSTO members would have little room to stand against Moscow. However, violation of the agreement could serve as a pretext for broader international condemnation and, potentially, strong action against Russian aggression. Complicating matters further is that an attack on one state is viewed as an attack against all. Given Russia's assertiveness elsewhere, a conflict with Kazakhstan would call into question the legitimacy of CSTO for all members. If some of the other states were to stand with Astana, it would heighten the Kazak argument before the international community that Moscow's acts were unlawful. In virtually any scenario whereby Russia encourages separatists in northern Kazakhstan, it is quite probable that Astana would have limited military response options. Rather, making a legal case against the Kremlin carries with 
it perhaps the best chance of preventing further destabilization. CSTO could serve as a mechanism for further bolstering Kazak claims.

When compared to CSTO, the SCO architecture requires less of a political commitment. The state parties to the accord are China, Kazakhstan, Kyrgyzstan, Russia, Tajikistan, and Russia. Interestingly, no collective or mutual-defense commitment amongst the SCO members exists. However, a heavy emphasis is placed on confronting extremism, separatism, and terrorism. In 2007 the SCO took defense one step further by signing an agreement with the CSTO to enhance partnership on security promotion and countering international and organized crime as well as drug trafficking. An important distinction must be made that while the SCO has promoted joint military activities, it has consistently stopped short of reaching an accord on mutual defense. "What holds the SCO together is its self-understanding as a 'multifunctional regional club' that covers a broad spectrum of soft-power cooperation (education, energy policy, infrastructure, trade, finance) and unites its members in combating the 'three evils' (separatism, terrorism, extremism)" (Kreikmeyer 177). For Kazakhstan, though, the SCO creates some very intriguing international law-oriented opportunities for countering possible Russian aggression.

The SCO's mission to confront separatism and extremism in particular should be exploited by Astana in the event of conflict with Moscow. Examining the manner with which Russia military and intelligence personnel engineered Crimea's secession from the Ukraine provides a potential blueprint for how the Kremlin might approach northern Kazakhstan. In particular, if Russia uses a combination of special forces, intelligence units, and separatists on the ground, then individuals in northern Kazakhstan will certainly have to declare their own secession. Very quickly Astana can move within the SCO to declare this a separatist movement requiring the member states to take action. The interesting question will then become whether the SCO members will rally to Kazakhstan's support. More than likely, the other states will not oppose Russia's aggressive actions. While many are likely to be displeased with Moscow's stance, the political risks of opposing the Kremlin may prove to be too great. However, if the SCO does not support Kazakhstan, then that may open the door for other states to provide assistance. Countering this argument, though, is the fact that

if China's bilateral security co-operation with its Central Asian neighbours was initially limited to providing military protection for pipelines, in recent years it has increasingly engaged in military activities in all three Fergana-Valley states with an eye to the security situation at the Afghan border, doing so without coordinating these activities with its SCO partner Moscow. (Kreikmeyer 178)

The unilateral actions Beijing has taken without really emphasizing the Kremlin's role speaks to a possible increased willingness on the part of the Middle Kingdom to deal with problems on its periphery. Furthermore, if China does not support Kazakhstan, it is well within the realm of the possible that the Europeans and the US may 
attempt to offer support. Regardless, the basis for Astana's legal claims hinges on its ability to portray Russia as a blatant violator of both parties' security commitments.

Along a slightly different path, Kazakhstan can also make its case before the UN. Going to the General Assembly would provide Astana a tool for voicing its legitimate concerns in front of the entire international community. Simply to raise awareness and to confront Moscow in the public relations sphere there is no better option. Kazakhstan could certainly argue that Russia has failed to provide a reasonable casus belli - a provocation warranting military conflict - for its aggressive actions. Moscow will more than likely claim that Astana has neglected and abused the rights of its ethnic Russian minority. However, Kazakhstan has treated all of its ethnic minorities well since its independence from the Soviet Union. Its treatment of such groups to date will only work to undercut Russia's claims. As with any issue, some states will fervently support Astana and some will ardently back Moscow. Therefore, it is the states in the middle ground that Kazakhstan must work to convince. Presenting its case before the UN will give Astana a tool to advocate for Russia’s blatant violations of international law. Furthermore, if such efforts fail, then there is "nothing in the present [UN] Charter [that] shall impair the inherent right of individual or collective self-defence if an armed attack occurs against a Member of the United Nations, until the Security Council has taken measures necessary to maintain international peace and security" (UN Charter Article 51 para 21). This statement in the UN Charter effectively grants Astana the right to respond militarily if it deems necessary. Maneuvering before the General Assembly is absolutely a necessity in winning to its side states that might be willing to provide some measure of support to Kazakhstan.

\section{POLITICAL CONTEXT}

If Moscow chooses to create a new semi-autonomous state out of Astana's northern territory, it will be accepting tremendous risks. The Kremlin's standing across much of the international community has been weakened in recent years. Its actions in Georgia and the Ukraine have enabled its detractors to portray Russia as an imperialistic state pursuing pre-modern policy ambitions:

Mr Putin has used the Ukrainian crisis to establish some dangerous precedents. He has claimed a duty to intervene to protect Russian-speakers wherever they are. He has staged a referendum and annexation, in defiance of Ukrainian law. And he has abrogated a commitment to respect Ukraine's borders, which Russia signed in 1994 when Ukraine gave up nuclear weapons. ("Russia and Ukraine” para 8)

Even the Putin Administration's approach to domestic debate and, more to the point, its brutal approach to dissension suggests the potential for growing instability in Eurasia. Kazakhstan must leverage fears over Russia’s new imperialism. Astana can portray the Kremlin today as a new Soviet Union. In so doing, it can rally support from China and the US in particular because Russian incursions into Central Asia threaten Beijing and 
Washington's interests as well. To ward off the threat from Moscow, Kazakhstan must exhaust not only its legal options, but also its political ones. Only through a holistic and whole-of-government approach can Astana hope to force the Kremlin's withdrawal.

Kazakhstan must turn to the People’s Republic of China (PRC) to potentially thwart Russia's incursions. What makes Astana unique is its role as a major economic thoroughfare. Beijing values the region as a means to move goods and people across Eurasia. Specifically, Central Asia serves as an overland route from China to gain access to vital energy resources in the Middle East. Conversely, the PRC is able to use Kazakhstan as one element of the bridge that enables it to move goods overland to Europe. Already "Kazakhstan is building a dry port and rail yard at Khorgos, in the desert on its eastern border with China, that will help to realise China's multibillion-dollar plans for a 'New Silk Road"” "The New Silk Road" para 1). Collectively, it is in Beijing's best interests to maintain the status quo in the region. Russian-engineered political instability in Astana only threatens China's interests. Kazakhstan can leverage the potential degradations in its effectiveness, efficiency, and stability to advocate for PRC involvement in its dispute with the Kremlin.

Beyond just the economic interference that would impede Chinese growth are far more serious political concerns. A Russian drive into Central Asia is reminiscent of Tsarist Russia and Soviet Union days. If Beijing does not respond to Moscow's aggression in Kazakhstan, it will risk permitting Russia to gain control over vital economic trade routes. The aforementioned New Silk Road has been touted as a "vision of Xi Jinping, China's president, who has championed it as an alternative to American-controlled sea-lanes. On November $8^{\text {th }}[2014]$ Mr. Xi pledged \$40 billion to 'break the connectivity bottleneck' in Asia" ("The New Silk Road” para 4). Perhaps more important from Beijing's perspective, if Russia were to succeed in Kazakhstan, it would further establish a cordon to China's west. With the continuing US presence in the Asia-Pacific region, the Middle Kingdom can ill afford to allow the Kremlin to enact its own containment strategy. With that being said, with the Russian Far East and Siberia in the north, Central Asian territories to the west, and India and Vietnam to the south, Russia would suddenly be well-positioned against China. In some respects, the security environment facing the PRC would look little different from what that of the early Cold War. This is the plausible future strategic environment Kazakhstan must present to China. In order to garner Beijing's support, Astana must clearly articulate the possibility that cutting a semi-autonomous state out of Kazak territory brings Russia one step closer to assuming a position of strength in Eurasia. Only by clearly presenting the potential drawbacks to China of a Russian incursion into Kazakhstan can Astana hope to win Beijing's support.

In a similar fashion, the Nazarbayev Administration will need to work the Washington angle in an effort to ward off Moscow's appetite for territory. Much like China, a plethora of compelling reasons exist that help explain why the US would consider embroiling itself in such an affair. From a pragmatic standpoint, and arguably 
most important of all, Kazakhstan would be the third country in less than a decade to be victimized by Russian incursions. If a similar fate were to befall Astana, it would greatly erode the confidence of the former Soviet republics and Warsaw Pact states in Washington's deterrence and assurance practices. Indeed, Moscow has gone so far as to argue "that it is not fighting Ukraine, but America in Ukraine. The Ukrainian army is just a foreign legion of NATO, and American soldiers are killing Russian proxies in the Donbas. Anti-Americanism is not only the reason for war and the main pillar of state power, but also an ideology" ("What Russia Wants" para 11). Even more troubling, if the US fails to respond to yet more Russian aggression, countries in the Asia-Pacific region facing China’s ominous threat may question Washington's resoluteness. Consequently, the US must be willing to take demonstrative action to signal clearly and irrevocably to its allies and partners that it does not accept Russia's actions. Astana can leverage Washington's position to receive needed supplies and, at the very least, place sanctions on Russia. Kazakhstan must encourage US participation to dissuade further Russian territorial acquisitions; however, Washington also has an opportunity in this crisis.

The US can mold this opportunity to reassert its position as a resolute advocate of freedom and democracy globally:

Mr Putin has taken to arguing that Russian values are fundamentally at odds with Western liberal ones. He now has the tools to intervene on his borders and beyond so as to upend the post-Soviet order. That might be in Transdniestria, a slice of Moldova that has hosted Russian troops since the early 1990s. Or in Kazakhstan, which has a large Russian population in the north. ("Russia and Ukraine" para 9)

However, as has been mentioned previously, Kazakhstan does not have a history of mistreatment of its Slavic minority. Therefore, there is little to justify separatist actions in its northern territories. Rather, given Russia's recent history of engineering secessionist movements along its periphery, a fairly high probability exists that Moscow would be supporting a smaller, more militant element of the ethnic Russian population. In this context, the US can justify supporting Kazakhstan under the supposition that the Kremlin is only representing a fringe section. This must be the approach Astana takes when making its case in Washington. The Nazarbayev Administration has the opportunity to advocate US support as a means to protect the interests of the state as a whole. In the face of an ominous threat from Moscow, Astana and Washington should present themselves as working in concert in the pursuit of regional and strategic stability. If Russia were to threaten Kazakhstan next, a number of political instruments, in addition to historical and legal mechanisms, can be leveraged to thwart the Kremlin's aggressive posture.

\section{KAZAKHSTAN SPECIFIC RECOMMENDATIONS}


Given Russia’s growing assertiveness along its near abroad, the risk of further Eurasian conflict is only increasing. The cyberattack against Estonia in 2007, the invasion of Georgia in 2008, and the ongoing conflict in the Ukraine have created an extremely tenuous environment among Russia and its neighbors. The utter disregard Moscow has shown toward the territorial integrity of its neighbors calls into question security across the region. With the change in Russia's posture, the states along its borders must adopt appropriate measures to deter aggression from their powerful neighbor. To prevent incursions, Kazakhstan must undertake defensive, economic, and social options that adequately build up its deterrent capacities. This will require that Astana begin fostering regional and strategic partnership capacity. Russia’s ominous position over Central Asia could serve as a motivating tool driving Kazakhstan, Kyrgyzstan, Tajikistan, Turkmenistan, and Uzbekistan toward one another. In a similar vein, Astana can certainly improve cooperation with Beijing and Washington. "Kazakhstan must therefore necessarily develop a multi-vector strategy aimed at collaboration and cooperation with other countries, integration projects and military-political blocs. This is especially important now, when Kazakhstan and Central Asia as a whole are facing serious challenges and threats" (Diyarbakirliglu and Sureyya 73). In parallel, trade space will emerge by which Kazakhstan can begin to separate itself from Russia. Astana will also have to improve its domestic outlook in order to minimize separatist desires as much as possible. A comprehensive and holistic approach to domestic and foreign policy is the best means of fortifying Kazak autonomy.

\section{DEFENSE ENGAGEMENT OPPORTUNITIES}

Astana must work with both its regional partners and potential great power patrons to prevent any future incursion on the part of Russia. "Kazakhstan's foreign policy, as well as that of the Central Asian region as a whole, has been shaped by a complex set of opportunities and dangers. In fact, much of the literature sees Central Asia as 'a region of intense rivalry and a potential geopolitical flashpoint,' and focuses on the role of Kazakhstan's oil policy in the 'Great Game' of the world's powers" (Zabortseva 320). Across the board, there must be a greater necessity to increase the mechanisms for dialogue, joint training activities, and other cooperative tools. More specifically, Kazakhstan must work to more closely to integrate its planning with that of its neighbors in Central Asia. The common threat posed by Moscow could quite easily motivate the region into more collective defense activities than ever before. In a similar vein, China and the US can prevent further Russian encroachments beyond its own territory by bolstering the domestic deterrence capabilities of the Kremlin's neighbors. Kazakhstan presents a unique opportunity for all the parties involved because bolstering its defensive capacity will reduce the likelihood of Russia's aggression.

At the regional level, the Central Asian states must take steps to separate themselves from Russia. In particular, the CSTO and SCO will still present value because they could limit Moscow's policy options. While 
"Moscow's long-term goal of maintaining its status by deepening inter-institutional relations with the CSTO and the SCO" (Kreikmeyer 181) could lead to a forfeiture of the Central Asian states' autonomy, it can also work in the same manner toward Russia. Alternatively, no reason exists why an additional collective security accord amongst the regional states could not exist in parallel to CSTO and SCO. On the contrary, such an arrangement would serve to promote integration amongst the regional states. Once this new organization is established, Kazakhstan will enjoy the support of partners more willing to assist in case of a Russian incursion. In the Georgian and Ukrainian cases, the isolation of both only made it easier for the Russians to adopt an aggressive posture, so Astana will find itself in a much stronger strategic position, particularly if Russia is forced to take more provocative action, if it unites in self-defense with other nations. Perhaps just as important, Kazakhstan will be in a much more stable operational environment once it has improved ties with its regional partners. The additional defense capacities will make Astana a far less inviting target for Moscow. Publicizing joint exercises and developing practices and procedures to improve coordination amongst the five states will message regional and international entities that Astana and its partners are serious. Maturing partnerships in Central Asia will make Kazakhstan a far more realistic opportunity for Chinese and US engagement.

Improving engagement with Beijing is crucial in preventing aggression from Moscow. The twenty-first century has borne witness to tremendous growth in People's Liberation Army (PLA) capabilities. The Chinese have gone to great lengths to make their military far more flexible and responsive. In parallel, the PRC has taken a more assertive stance in promoting its interests abroad. As was previously mentioned, Kazakhstan has sufficient economic value to warrant China's interests. Moving a step further, Beijing has attempted to assert itself as a budding Asia-Pacific and, potentially, global power. The Middle Kingdom's positioning requires far greater engagement when its regional interests are threatened. "In Kazakhstan $\$ 30$ billion of announced deals included a stake in Kashagan, the world's largest oil discovery in recent decades" ("China in Central Asia para 2), thereby elevating China's interests in the region. If Russia is able to assert itself in Central Asia, the PRC's prestige and image will be severely damaged. The important point for analysis now lies in identifying how Beijing can message its posture to Moscow.

Without overly committing itself to Kazakhstan, China must strengthen Astana’s deterrence capabilities. This does not necessarily imply agreeing to a formal partnership. The Nazarbayev Administration must appreciate this and seek other mechanisms that more subtly demonstrate the Xi Administration's position. Kazakhstan must pursue dialogue mechanisms to discuss a wide variety of defense-related issues. Ostensibly the major thrust of these engagements must be toward improving cooperation on politically low-risk activities. For instance, both parties can improve joint counterterrorism, counternarcotic, and humanitarian disaster relief response operations. Kazakhstan can use "China’s chief concern - the threat posed by Uighur separatists and 
their sympathisers in Central Asia" "China in Central Asia para 5) — as an incentive and justification for increased collaboration. In a broad sense, these activities will not necessarily lead to a full collective security agreement, but they will begin to place doubt in the minds of Russian planner and policy makers. Embarking upon these cooperative engagements will further improve the Kazak training and, at the very least, give the Russians pause before they take a more assertive posture. By improving cooperation with Beijing, Astana will be in a better position deter aggression from Moscow.

Perhaps more importantly, China can emphasize the value it places in Kazakhstan by negotiating weapon and support material sales while also speaking on behalf of Astana at various regional and international forums. Offering weapon sales to Kazakhstan will substantially boost its operational and strategic deterrence potential. Furthermore, offering Chinese weapon systems gives Beijing the justification necessary to deploy trainers and advisors. These individuals can monitor the situation on the ground and, once again, create concern for Russian planners - they certainly could ill afford any Chinese fatalities. In a similar fashion, the PRC can provide the Kazaks with auxiliary support that, for example, could boost the indication and warning element of Astana’s early warning systems. This would provide them with a far better understanding of the operational picture if the Russians were to attempt an incursion. China can then add to its support by voicing the value it places in its partnership with Kazakhstan abroad. Chinese officials can make clear that they value the cooperation they share with the Kazaks. Without necessarily committing to Astana’s defense, Beijing's leadership can create uncertainty in Moscow's planning efforts. Ultimately, "conflicts along China's borders can not only increase the presence and thus potential influence of other great powers, creating strategic challenge, but may also directly involve China" (deLisle and Goldstein 207). Taken collectively, China could go to great lengths to create doubt in Russian government circles.

Kazakhstan can further enhance its ability to deter Russian attempts at fostering succession movements by improving its cooperation with the US. Already Astana and Washington cooperate on issues like Afghanistan's reconstruction and countering terrorism. The Obama Administration and future presidents can support Kazakhstan through both political and military mechanisms. From a diplomatic standpoint, the US has historically demonstrated a willingness to build partnership capacity in at-risk areas. "The United States' prime motive - which is to contain Russia can be achieved by promoting regional integration. Regional states cannot play their role if they remain isolated or if any opportunity to link their economy to the global market would be denied to them. Through economic activity the Russian exploitation of the natural resources would be contained" (Fatima and Zafar 638). Particularly under the present circumstances, promoting collective security-like arrangements in Central Asia will help contain Russia. Even a small commitment from the US will indicate a willingness to support Kazakhstan in the event of confrontation. Given what occurred in Georgia and the Ukraine 
- where there was virtually no US commitment prior to conflict - even a small demonstration by Washington may change Moscow's strategic planning. Further diplomatic engagements will only continue to build partnership capacity and improve Kazakhstan's deterrence posture.

Parallel to political efforts, Washington will need to assist Astana with its military capabilities. Similar to China, the US must be willing to increase defense sales in order to raise the costs for Russia if an attack were to occur. In doing so, Washington can demonstrate a greater commitment to Kazakhstan, but probably more of a concern for Russia is how such sales may further complicate any aggressive actions Moscow may undertake. Furthermore, the US can offer training assistance, operational advisors, and technical support in niche capabilities that, if developed, will offer Kazakhstan asymmetrical advantages. These benefits will give Astana not only political potency but also a stronger series of defensive options. As has been previously mentioned, when factoring in a broad range of tools, Kazakhstan can position itself far better in terms of the possibility of deterring Russia. "In each region the U.S. should pick a linchpin partner to empower" (Schoen and Kaylan 296), and Astana can serve that goal in Central Asia. Ultimately, building partnership capacity with other great power patrons is critical to dissuading aggression from the Kremlin.

\section{ECONOMIC LEVERAGE}

Defense is only one element in strengthening Kazakhstan's position vis-à-vis Russia. It must also strengthen its economic footing in the region; for if Astana can successfully position itself as a more vital member of the broader Eurasian business world, it will make instability within its borders far more damaging abroad. To be fair, the government has already shaped the "country into a major oil-and-gas exporter and overseen the establishment of Central Asia's highest standards of living" ("Tony Blair in Kazakhstan" para 3). With that being said, Astana can do much more. Essentially, Kazakhstan must leverage globalization and the assets it has to develop dependency relationships. As its ties with other states deepen, Kazakhstan's neighbors and other partners will find ignoring potential Russian aggression increasingly difficult. In order to become a more vibrant regional economic power in the long run, Astana will need to develop a broad set of relationships both regionally and globally. Improving in both defensive and social characteristics will improve the perception outsiders have of its stability and security, thereby increasing the likelihood of foreign direct investment (FDI) and other business opportunities. As this process both broadens and accelerates, Kazakhstan will then need to begin creating distance between its economy and Russia's. More than likely such a maneuver will require that Astana leave the Eurasian Union - causing a rift with the Kremlin - to remove itself from the floundering Russian economy. However, diversification is greatly needed in order to improve Kazakhstan's positioning. 
Astana has already begun to diversify its exports and is currently attempting to reach an increasing number of markets far afield. Already the Nazarbayev Administration presides over "an economy that is a model of prosperity compared with the basket cases elsewhere in Central Asia" ("Elections in Central Asia" para 5). Despite its successes, the government's modernization and diversification projects must not only continue, but the intensity of these efforts must also increase. In particular, Kazakhstan can leverage economic and political instability in Russia to bring increasing energy reserves to China and elsewhere in East and South Asia. Focusing on delivering energy to the wider region, particularly through China, could provide a secure revenue stream independent of Russia (as most pipelines to Europe pass through Russian territory). This is an ambitious plan but one that can be achieved gradually. In the meantime, Kazakhstan has already begun efforts to diversify its export portfolio. For instance, drawing on its history as a ranching society, "since 2010, under a $\$ 1$ billion, five-year programme, the government has flown in 50,000 Black Angus and Hereford cattle (and lots of frozen semen) from Australia, Canada and America" ("Steaks" para 2). More importantly, Astana is also seeking to target niche capabilities that can then form more substantial dependencies. Work in specific manufacturing sectors (i.e. telecommunications and petrochemicals) must continue in order to develop business partnerships abroad. If Kazakhstan can continue to mature these industries, they will attract partners that, through their governments, will bolster Astana’s deterrence mechanisms.

Embarking upon programs designed to energize Kazakhstan's export industries will attract attention and, in conjunction with other projects, lead to greater FDI. Specifically, Astana must work to increase physical capital investments. Foreign firms have the liquidity the country needs in order to augment internal programs. "It is rich in all the world's strategic natural resources" (Kaplan 185), which can be leveraged as an initial lure for attracting foreign enterprises. Arguably more important are the long term relationships FDI offers. Once a company has expended resources on a state's territory, instability in the area becomes a serious detriment. In the case of Kazakhstan, its work to bolster its defenses will provide the initial incentive for foreign firms to enter the marketplace. However, in a symbiotic manner outside businesses will provide a second deterrent. Once they have become firmly entrenched, then any Russian incursion not only threatens the Kazak economy, but those investors in Kazakhstan. Additionally, as physical capital investments hasten, Astana will then be in a position to promote its human capital. Training indigenous personnel is in the best interests of companies that are looking to separate themselves from their competition. Developing good working relationships with the local population is a prudent step both in the workplace and in the market. More importantly for Kazakhstan, investing in its people holds the potential to raise awareness on issues that are effecting the state. In the event that Russia should take aggressive action, a more affluent population could raise awareness abroad and negatively impact Moscow through a variety 
of means and mechanisms. Invariably, there is tremendous value in raising Kazakhstan's identity in the business world.

It would be erroneous to ignore current concerns over lax governmental enforcement of ethics. Unfortunately, a culture developed in the Soviet Union where auxiliary costs became a means to improve one's position vis-à-vis business, governmental, or personal dealings. It became commonplace for individuals or groups in a position of strength to exact additional costs on others. Today "investors of all kinds worry about the declining predictability of Kazakhstan's regulatory and legal environment,' says Mariyam Zhumadil of Halyk Finance, an investment bank in the commercial capital, Almaty" ("Oil Firms" para 4). The problem for Kazakhstan is how these potential improprieties have left the bottom lines of firms seeking to do business in the country vulnerable. For instance, "in 2010 the government filed a $\$ 1.2$ billion tax claim against the consortium that operates an oil field, Karachaganak, while making noises about breaches of environmental rules, not long after expressing an interest in buying a stake in the field. Later the consortium gave it [a] 10\% return for it agreeing to expand the field" ("Oil Firms" para 4). If Kazakhstan wants to retain its sovereignty and territorial integrity, it can ill afford such a reputation for unethical actions. Astana will need to promote greater integrity, transparency, and governmental and private accountability.

If Kazakhstan can begin to gather momentum for its economic modernization efforts and partnerships abroad, then its dependency on Russia will be greatly diminished. With further internal developments and cooperation maturation, Astana can further diversify its engagement strategy. Ultimately, the focus of this plan must be gaining separation from Moscow. In particular Kazakhstan can leave the Eurasian Union - the customs union developed by the Kremlin. While Astana may have originally hoped for Moscow's assistance in attracting foreign investment, the reality that has unfolded has not met expectations. Rather, the Eurasian Union has only served the best interests of the Kremlin since "Mr Putin plainly views it as a way to project Russian power" (“Kazakhstan” para 3). To make matters worse, as Russia’s economy has slowed in recent months, Kazakhstan has suffered in parallel. With such a high degree of integration, Astana has clearly felt the impact of the weakening ruble. Leaving the Eurasian Union will weaken the control Russia has over Kazakhstan. As a result, Astana will be in a much better position to defend itself if the Kremlin attempts to forcibly divide the country. Furthermore, widening the gap between Russia and Kazakhstan may very well prove to be in Astana's future. "Thanks to the Proton [rocket], which launches only from Baikonur, Russia has held a third of the commercial space-launch market over the past decade" ("Kazakhstan's Spaceport" para 4). Separating from Moscow could very easily be in the best interests of the Nazarbayev Administration. Regardless, Kazakhstan can only create the breathing space needed to abandon Russia if it has strong alternatives.

\section{SOCIAL PROGRAMS}


Investing in human development is a critical element to any long term strategy for improving the fortunes of a state. Raising standards of living and improving societal functions for a people are critical to improving the long term happiness and prospects for any nation. In this situation, Kazakhstan happens to have an acute need for societal development. Its long term history over centuries has been marred by a near-constant struggle for survival. And since the Soviet Union era, it has struggled to break free from the communist legacy of heavy industry and poorly functioning societal structures. Improving governmental and private transparency as well as election legitimacy will also help improve the state's attractiveness to outsiders. To escape these dynamics, Kazakhstan must place greater emphasis on human capital development and social welfare programs. This will lead to "rule under law, where everyone in society, rulers and ruled, are subject to the same laws" (Mahbubani 84). As these programs begin to take effect, Astana will be in a far better position to reduce ethnic tensions and promote loyalty to the government.

Human capital investment is critical to raising the standards of living in Kazakhstan. Today, with simple investments in cattle ranching, local Kazaks are "now selling home-grown steaks in Astana, the capital, for half the cost of an imported Argentine cut" ("Steaks" para 3). Yet the government must take further steps. Specifically, in developing niche capabilities, Astana must mature the talent pool that firms can draw from. Improving the potential workforce will only make it more likely that foreign businesses will want to invest in Kazakhstan. More to the point, bolstering the abilities of the Kazak people would increase the feasibility for more high technology companies establishing operational centers in the state. Moving past more traditional manual labor and lesser skilled employment is an important element to raising the overall standards of living. Beyond just improving the professional quality of the citizenry, human development will strengthen the overall society. The Kazak people will be able to take on a more active role in their own government and fortunes. A more affluent society is also more likely to have a larger footprint abroad. Consequently, in the event of Russian aggression, Kazakhstan will be in a far better position to raise its concerns internationally. This will play an extremely important role in increasing the costs to the Kremlin of even a subversive campaign inside Kazakhstan.

In a more pointed fashion, bolstering social welfare programs is absolutely critical to minimizing secessionist tendencies. "There is great wealth, but it is concentrated in two cities, Almaty and Astana. Yet in the potholed villages scattered across the rest of this vast country, the world's ninth-largest by land area, basic infrastructure is crumbling, even the oil-rich areas lack regular supplies of clean water and electricity" (“Kazakhstan's Political Stability” para7). The Nazarbayev Administration would substantially benefit from promoting a more equal society across geographic and ethnic lines. Investing in public services, education, family planning, and elsewhere will enable the state to raise standards of living and societal norms. Over the long term, this will limit any potential for rebellious movements. While there may always be fringe movements in northern vol.08, nº. 03, Rio de Janeiro, 2015. pp. 1555-1582 1578 
Kazakhstan looking to break away, Astana can limit this element to such an extent that it becomes negligible. As a result, Russia will be unable to foster a separatist movement in the region, and without one they will stand little chance of avoiding a protracted engagement. Without greater investment in domestic welfare programs none of this is possible though.

To reduce the chances of ethnic tension, Kazakhstan can also take lessons from the Organization for Security and Cooperation in Europe (OSCE). This group promotes non-traditional security techniques as a means to put forward a holistic approach to improving stability. Already "OSCE Centres established in all five Central Asian states have pursued the Organization's comprehensive security-co-operation approach to varying degrees since 1998. Particularly in the area of transnational security threats, many projects exist that aim to encourage intraregional co-operation" (Kreikmeyer 178). In the case of Kazakhstan, OSCE could provide an ideal advisor because of its experience with developing governmental practices, minimal policing techniques, and migratory reform for instance. Astana should actively seek the group's advice on how best to improve its internal stability without increasing the government's footprint. If this can be achieved, then the Nazarbayev Administration will be in a better position to promote loyalty amongst its ethnic minorities. Furthermore, as was previously mentioned, concerns remain over Kazaks' private and public ethical values. Its previous standing as a Soviet state does not serve its reputation well. That is why Astana must go the extra mile in promoting governmental and private ethics. Taken as a whole, Kazakhstan can do more to improve its transparency, stability, and cohesiveness both internally and externally.

Elections and the overall legitimacy of the government must also be addressed as a means to improve the cohesion between the senior political leadership and general population. Unfortunately, Nazarbayev has "built up a personality-driven regime not unlike the one in President Vladimir Putin's Russia" ("Elections in Central Asia" para 2), which only works to weaken Kazakhstan's political legitimacy in foreign eyes. Sadly, "Mr. Nazarbayev is enshrined in Kazakhstan's constitution as 'leader of the nation.' He alone is allowed by law to stand indefinitely. He was not due to face voters until late in 2016. But, as he has done for every election since independence, he moved the date forward" ("Elections in Central Asia" para 4). The Nazarbayez Administration must look to distance itself from such an autocratic system. To do so would bolster the government's legitimacy both internally and externally. Particularly since "the president is genuinely popular, winning credit for the political stability and rising standard of living in his oil-rich nation" ("Kazakhstan's Political Stability" para 2). So, the likelihood of Mr. Nazarbayev winning reelection would be fairly strong. Consequently, Kazakhstan would be in a better position to both minimize separatist tendencies and generate popular support in repelling a potential Russian incursion. 


\section{CONCLUSION}

Moscow's growing assertiveness along its periphery is becoming an increasing concern for all involved in the region. Its use of Russian ethnic minorities as a justification to encourage secession movements abroad has served to destabilize regimes throughout Eurasia. Kazakhstan has been left in a particularly difficult predicament given the substantial Slavic minority population within its borders. Today, the Kremlin has been afforded a unique vantage point with respect to Astana. Given its relative dependence on Russia's economy and geographic isolation the Putin Administration could pressure the Kazak leadership into accepting a less than desirable resolution to any separatist incident(s). To deter such aggression the Nazarbayev Administration must foster greater partnership capacity with both potential regional and international partners. Only by building a strong series of dependency relationships can Kazakhstan hope to rally support in the event of conflict with Russia.

\section{DESAFIO DO CAZAQUISTÃO: A AMEAÇA REPRESENTADA PELA MINORIA ÉTNICA RUSSA DA ASTANA E O QUE ISSO SIGNIFICA PARA O DIREITO INTERNACIONAL}

\section{Resumo}

Durante dois séculos o Cazaquistão funcionou sob o jugo do imperialismo russo e soviético. Talvez o legado mais duradouro do período é a grande minoria étnica russa no norte do Cazaquistão. Ao longo dos últimos vinte e cinco anos desde que Astana declarou sua independência, tem havido pouco ou quaisquer sinais visíveis de tensões étnicas no Estado. Entretanto, o uso do Kremlin de minorias étnicas russas na Geórgia e na Ucrânia como justificativa para uma ação militar agressiva nos assuntos internos de ambos os Estados provou ser desconcertante para muitos dos vizinhos da Rússia. Talvez o maior agravante tem sido a falta de uma resposta em espécie pela comunidade internacional. $\mathrm{Na}$ ausência de uma ação mais demonstrativa, há uma preocupação crescente na Eurásia de que a Administração Putin estabeleceu um novo precedente em matéria de política regional. Independentemente disso, o Cazaquistão deve desenvolver uma campanha diplomática e planejamento estratégico coerentes para construir os meios e mecanismos necessários para dissuadir potencial agressão russa. Promover oportunidades de envolvimento de cooperação com os seus vizinhos regionais e parceiros internacionais oferece a contundência necessária para potencialmente dissuadir futura agressão russa. Envolvimento holístico para reforçar a defesa e a economia, e a elevação dos níveis sociais irá demonstrar a todos os envolvidos que Astana tem as ferramentas à sua disposição para conter a agressão estrangeira.

Palavras-chave: política internacional - Cazaquistão - conflitos territoriais - soberania - Direito Internacional

\section{REFERENCES}


ALLISON, Roy. Virtual Regionalism, Regional Structures And Regime Security In Central Asia. Central Asian Survey 27.2 (2008): 185-202. Academic Search Premier. Web. 14 Jun 2015.

BERMAN, Ilan. Implosion: the End f Russia and what it means for America. Washington D.C.: Regnery, 2013. Print.

CAMPBELL, Ian W. Settlement Promoted, Settlement Contested: The Shcherbina Expedition Of 1896-1903. Central Asian Survey 30.3/4 (2011): 423-436. Academic Search Premier. Web. 13 Jun 2015.

DELISLE, Jacques, and Avery Goldstein. China’s Challenges. Philadelphia: University of Pennsylvania Press, 2015. Print.

DIYARBAKIRLIOĞLU, Kaan, and Süreyya Yiğit. Kazakh Multi Vector Foreign Policy In Action. Alternatives: Turkish Journal Of International Relations 13.4 (2014): 70-82. Academic Search Premier. Web. 14Jun 2015.

FATIMA, Qamar, and Sumera Zafar. New Great Game: Players, Interests, Strategies And Central Asia. South Asian Studies (1026-678X) 29.2 (2014): 627-655. Academic Search Premier. Web. 14 Jun 2015.

FEIFER, Gregory. Russians: the People Behind the Power. New York: Twelve, 2015. Print.

FISK, Robert. The Great War for Civilisation: The Conquest of the Middle East. New York: Vintage Books, 2007. Print.

KAPLAN, Robert D. The Revenge of Geography: What the Map Tells us About Coming Conflicts and the Battle Against Fate. New York: Random House Trade Paperbacks, 2013. Print.

KREIKEMEYER, Anna. State, Criminality And Security In Central Asia: What Do Eurasian Regional Organizations Contribute To Security And Peace? Security \& Human Rights 24.2 (2013): 169-181. Academic Search Premier. Web. 14 Jun 2015.

MAHBUBANI, Kishore. The Great Convergence: Asia, the West, and the Logic of One World. New York: PublicAffairs, 2013. Print.

RASHID, Ahmed. Descent into Chaos: The U.S. and the Disaster in Pakistan, Afghanistan, and Central Asia. New York: Penguin Books, 2009. Print.

ROBERTS, J.A.G. The Complete History of China. Gloucestershire: Sutton Publishing, 1996. Print. SARSEMBAYEV, Azamat. Imagined Communities: Kazak Nationalism And Kazakification In The 1990s. Central Asian Survey 18.3 (1999): 319-346. Academic Search Premier. Web. 14 Jun 2015

SCHOEN, Douglas E. and Melik Kaylan. The Russia-China Axis: The New Cold War and America's Crisis of Leadership. New York: Encounter Books, 2014. Print.

THE ECONOMIST. China in Central Asia - Rising China, Sinking Russia. 14 Sep 20134. Web. 14 Jun 2015. Crimea Votes to Secede - Ukraine's Amputation. 17 Mar 2014. Web. 13 Jun 2015. The New Silk Road - Hardly an Oasis. 15 Nov 2014. Web. 12 Jun 2015. The War in Georgia - Russia Resurgent. 14 Aug 2008. Web. 13 Jun 2015. Tony Blair in Kazakhstan - Democratic Reforms, still TBA. 16 Nov 2013. Web. 12 Jun 2015. 
What Russia Wants - From Cold War to Hot War. 14 Feb 2015. Web. 13 Jun 2015.

Elections in Central Asia - No Choice. 4 Apr 2015. Web. 12 Jun 2015.

Kazakhstan - Steaks from the Steppe. 23 Aug 2014. Web. 12 Jun 2015.

Kazakhstan - The Bear on the Doorstep. 21 Jun 2014. Web. 12 Jun 2015.

Kazakhstan's Name - Don't Call me Stan. 22 Feb 2014. Web. 12 Jun 2015.

Kazakhstan's Political Stability - Heavy Hangs the Head. 3 Oct 2013. Web. 12 Jun 2015.

Kazakhstan's Spaceport - Final Countdown. 8 Nov 2014. Web. 12 Jun 2015.

Oil Firms in Kazakhstan - Cash All Gone. 11 Oct 2014. Web. 12 Jun 2015.

2015

Pax Sinica - China is Trying to Build a New World Order, Starting in Asia. 20 Sep 2014. Web. 14 Jun

Russia and Ukraine - Insatiable. 19 Apr 2014. Web. 14 Jun 2015.

UNITED NATIONS. Charter of the United Nations. 14 Jun 2015 < http://www.un.org/en/documents/charter/chapter7.shtml>.

ZABORTSEVA, Yelena N. Rethinking The Economic Relationship Between Kazakhstan And Russia. EuropeAsia Studies 66.2 (2014): 311-327. Academic Search Premier. Web. 14 Jun 2015.

Trabalho enviado em 27 de junho de 2015.

Aceito em 03 de agosto de 2015. 